\title{
Seeking Consilience for Sustainability Science: Physical Sciences, Life Sciences, and the New Economics
}

\author{
Joshua Farley
}

Department of Community Development and Applied Economics, University of Vermont, 205 B Morrill Hall, Burlington, VT 05405, USA; E-Mail: jfarley.uvm@gmail.com; Tel.: +1 8026562989; Fax: +1 8026561423

Submitted: 29 January 2013 | In revised form: 10 April 2014 | Accepted: 11 April 2014 |

Published: 5 May 2014

\begin{abstract}
The human system, driven largely by economic decisions, has profoundly affected planetary ecosystems as well as the energy supplies and natural resources essential to economic production. The challenge of sustainability is to understand and manage the complex interactions between human systems and the rest of nature. This conceptual article makes the case that meeting this challenge requires consilience between the natural sciences, social sciences and humanities, which is to say that their basic assumptions must be mutually reinforcing and consistent. This article reviews the extent to which economics is pursuing consilience with the sciences of human behavior, physics and ecology, and the impact full consilience would have on the field. The science of human behavior would force economists to redefine what is desirable, while physics and ecology redefine what is possible. The challenges posed by ecological degradation can be modeled as prisoner's dilemmas, best solved through cooperation, not competition. Fortunately, science reveals that humans may be among the most cooperative of all species. While much of the mainstream economic theory that still dominates academic and the policy discourse continues to ignore important findings from other sciences, several sub-fields of economics have made impressive strides towards consilience in recent decades, and these are likely to change mainstream theory eventually. The question is whether these changes can proceed rapidly enough to solve the most serious problems we currently face.
\end{abstract}

Keywords: anthropocene; cooperation; human behavior; interdisciplinarity

\section{Introduction}

Human impacts on the planet are now on the scale of geological forces, to the extent that the current era is increasingly referred to as the anthropocene [1]. These impacts threaten to exceed planetary boundaries, risking catastrophic impacts on humans and the rest of nature [2]. If we hope to meet fundamental

(C) 2014 by the authors; licensee Librello, Switzerland. This open access article was published under a Creative Commons Attribution License (http://creativecommons.org/licenses/by/3.0/). 
human needs in the near term without destroying planetary life support functions required by all species, we can no longer separate the study of human systems and natural systems, but must instead adopt a transdisiplinary, holistic approach to science that "seeks to understand the fundamental character of interactions between nature and society. Such an understanding must encompass the interaction of global processes with the ecological and social characteristics of particular places and sectors." ([3] p. 641) Earth Systems Science [4] and Sustainability Science [3] exemplify this approach.

The steady accumulation of human knowledge has made it impossible for any individual to be an expert in all areas of study. Scientific progress therefore has relied on increasing specialization in narrow areas, as exemplified by the study of individual disciplines within the universities. This specialization has resulted in impressive advances, but it has also created barriers between fields of knowledge. These barriers are not only serious obstacles to the advance of sustainability science, but also can lead individual disciplines to build on beliefs or assumptions that contradict those of other disciplines. Even if specialization is necessary, it is essential that facts and theories within a discipline are internally consistent, and the facts, theories and inductions from one discipline do not fundamentally contradict those from another. In particular, "when different disciplines focus on the same object of knowledge, their models must be mutually reinforcing and consistent where they overlap" ([5] p. 4). When there is disagreement, it should be settled with empirical tests, experiments and observations to lend support to one hypothesis over another, and not simply ignored. This is very much the case in the natural sciences. Theories in cell biology do not contradict theories in evolutionary biology, and both are consistent with the theories of chemistry and physics. Even when facts and theories may seem to contradict each other, as in the case of quantum theory and the theory of relativity, physicists pay close attention to the contradictions, and assume that they will eventually discover basic physical laws that resolve them. This type of agreement across fields and disciplines is known as consilience [6]. Sustainability science demands consilience as an explicit objective.

Consilience is far less advanced in the social sciences than the natural sciences [7]. Facts, theories and inductions from one social science not only frequently contradict those from another, but also frequently contradict the natural sciences. The most important example of this in the context of sustainability science may be in the discipline of economics for two main reasons. First, economic activity-defined as the transformation by humans of raw materials and energy into goods and services intended to satisfy human wants and needs-is the central cause of the most serious sustainability challenges that human society currently faces: global climate change, biodiversity loss, land use change, ocean acidification, ozone depletion, waste emissions in excess of the planet's absorption capacity, and excessive dependence on rapidly diminishing stocks of fossil fuels. Second, economics arguably has the most influence of any social science on policy decisions. This article will focus on consilience in mainstream economics, which has the greatest impact on policy decisions, and hence the greatest influence on sustainability.

Consilience is not the occasional incorporation of theories or insights from the natural sciences into the social sciences, but rather the explicit acknowledgement that the social sciences must be consistent with the common understanding of fundamental laws that the natural sciences have built up over decades and centuries. This does not mean however that the social sciences should be explicitly modeled on the natural sciences or should blindly adopt its methods. There are profound differences between the two fields. Theories in the social sciences can affect reality while theories in the natural sciences cannot. For example, if people believe the theory that abruptly ending quantitative easing will cause the stock market to crash, this could lead to a panicked sale of stocks, triggering a crash. Eminent mathematical economist Georgescu-Roegen argued that the mathematical models of neoclassical economics-explicitly drawn from the methods of mechanical physics-are illsuited for the modeling the qualitative change characteristic of steadily evolving economies [8]. Furthermore, though many physicist believe that if we knew the position and velocity of all particles in the universe it would be possible to retrodict the past and predict the future, and some biologists believe that genes determine behavior, the economy should not be described as a mechanistic system devoid of purpose and will, which leaves no room for policy [9]. The social sciences should be informed and shaped by, but not reduced to, the natural sciences [10].

Consilience is also not a one-way street: economists have long called for the natural sciences to become more consilient with economics, complaining about the arrogance of "some scientists in assuming that they are competent to comment on the economic problems of the environment without knowing any economics" [11]. Numerous economists have (correctly) pointed out that limits-to-growth theorists since the time of Malthus have often failed to account for role of the price mechanism and human ingenuity in alleviating resource constraints (e.g. [12-14]).

Economics - conventionally defined as the allocation of scarce resources among alternative competing ends -is a broad field, characterized by many schools of thought with different degrees of influence, some of which have paid more attention to consilience than others. Ecological and biophysical economics for example explicitly strive for consilience with the natural and social sciences $[9,15-19]$, but these two fields are rarely considered part of mainstream economics. It is in 
fact a bit difficult to define mainstream economics precisely. An entry in an on-line encyclopedia of economics states that "we are all neoclassicals now... what is taught to students, what is mainstream economics, is neoclassical economics." [20]. Precisely defining neoclassical economics is also difficult. Some authors identify three core axioms: economic phenomena can only be explained as the result of individual actions; all human behavior is an effort to maximize the satisfaction of individual preferences; and equilibrium between supply and demand is the starting point for analysis [21, 22]. Other central themes found in most undergraduate textbooks include the assumptions that humans are rational, self-interested and insatiable, everything can be measured in monetary terms (monism), and preferences are exogenous; furthermore, Knightian uncertainty (immeasurable risk) is ignored, and the desirability of continuous economic growth is taken for granted (e.g. $[17,23])$.

In recent decades, serious theoretical and empirical challenges to the core tenets of neoclassical economics have shaken the field, and many economists argue that mainstream economics is transitioning towards greater consilience with the natural and social sciences. Colander et al. [24] argue that at "the edge" of the mainstream, leading economists are incorporating complexity theory, psychology, ecology and institutions into their theories. These leaders are strongly respected by their more orthodox colleagues, resulting in a continual evolution of the mainstream. However, Colander et al. also acknowledge that the mainstream economics of 15-30 years ago (neoclassical economics) is still taught to undergraduates. Hodgson speculates that institutional and evolutionary economics may become the new mainstream [23].

This article focuses primarily on the state of consilience within mainstream economics, while acknowledging the fuzzy boundaries of the field. At one extreme the article will address the material taught in undergraduate textbooks-hereafter referred to as orthodox economics - which is the only exposure most people receive to economics and arguably the most influential on policy decisions [17]. As Nobel laureate and leading textbook author Paul Samuelson stated "I don't care who writes a nation's laws-or crafts its advanced treaties-if I can write its economics textbooks" [25]. At the other extreme this article will address "the edge" of economics, and the new ideas that may be filtering into the mainstream. From the perspective of sustainability, however, The most important area for consilience is in the advice economists provide to policy makers.

Economics is conventionally defined as the allocation of scarce resources among alternative competing ends. From this definition, it follows that two areas of consilience in economics are particularly important. The first is the science of human behavior (e.g. psychology, neuroscience, evolution, and so on), which is relevant to both the ends that economic activity should pursue and the institutions compatible with human behavior. The second is the natural sciences, particularly physics and ecology, which are most relevant to understanding the means required to achieve those ends. We can only decide how to allocate resources after determining the appropriate ends and human compatibility with different institutional arrangements, and the available means, including their physical characteristics.

The structure of the paper is as follows. The first section following this introduction will focus on consilience with the science of human behavior. Subsections focus on rationality, self-interest and satiability, followed by a discussion of the extent to which consilience has occurred. The second section will focus on the natural sciences, with sub-sections on the laws of physics, and the laws of ecology, followed by a discussion of consilience. The third section will focus on the implications of consilience for the allocation problem, with subsections on the physical characteristics of the scarce resources, the laws of economics, and how we should allocate.

\section{Human Behavior, Ends and Institutions}

Modern economics arose from utilitarian philosophy, which viewed the maximization of utility-the achievement of the greatest happiness for the greatest number-as a moral imperative for society and the desired end of economic activity $[26,27]$. Since people experience diminishing marginal utility, classical utilitarian philosophy seemed to call for a more equitable distribution of resources. Many economists argued however that a major challenge to maximizing utility was the difficulty or impossibility of objectively quantifying utility or comparing utility between individuals. On the other hand, if people are rational they will prefer things that generate more utility to those that generate less, and their willingness to pay for different goods and services (including leisure and other nonmarket activities, the costs of which can be interpreted as the income foregone by not working) will reveal their preferences [28]. There is no need to directly measure utility. This result led mainstream economics to redefine utility and welfare as the satisfaction of individual preferences or tastes as revealed by willingness to pay $[26,29,30]$. Utility for society in the current period is therefore maximized when resources are allocated to those willing to pay the most for them, which also maximizes monetary value for the economy as a whole. In the words of a leading economist "the refusal of modern economists to make "interpersonal comparisons of utility" means in effect that they use wealth rather than happiness as the criterion for an efficient allocation of resources" ([31] p. 88). By "efficient", Posner means Pareto efficient (also known as Pareto optimal) in honor of Vilfredo Pareto, a central figure in the development of neoclassical economics. Pareto efficiency is defined as 
a situation in which it is impossible to make at least one individual better off without making another worse off. Under certain rigid assumptions, markets can be shown to allocate resources in a Pareto efficient manner. The central desired end of economic activity in mainstream welfare economics is Pareto efficiency, equivalent to the maximization of monetary value or economic surplus at any given point in time, brought about by the satisfaction of individual preferences in a market economy. Market competition however leads firms to sell their products at the lowest possible price to cover their factors of production, eliminating economic profit. The pursuit of profit leads firms to innovate, so that consumers can obtain more and better products at a lower price over time. Since a larger economy creates even more wealth, continuous economic growth is another desired end.

These conclusions emerged from fairly rigid assumptions about human behavior, including rationality, self-interest, and insatiability. They also rely on the assumption that we cannot make interpersonal comparisons of utility. The following three sub-sections will examine the rapidly accumulating evidence that refutes these assumptions, much of which was produced by economists at "the edge". The forth subsection below assesses the extent to which this evidence has affected mainstream economics.

\subsection{Are People Rational?}

The behavioral sciences, including behavioral economics and neuroscience, have done the most to challenge the notion that humans are perfectly rational. The polymath Herbert Simon first popularized the ideas of "bounded rationality" and "satisficing", which recognized that humans have limited cognitive capacity and limited information, and under these circumstances must settle for satisfactory rather than optimal decisions [32]. Tversky and Kahneman showed in rigorous experiments that human decisionmaking exhibits systematic biases. For example, most people are risk averse, and weight losses more heavily than gains of equal value. One can frame a single problem in a way that emphasizes either losses or gains and affect the decision making process [33]. As the title of two popular books emphasize, numerous experiments have shown that people are "Predictably Irrational" [34], and we can therefore use our knowledge of human behavior to "Nudge" [35] people in desired directions. Economist Milton Friedman argued that the test of a good theory is not its realism, but rather its ability to generate good predictions [36]; the assumption of economic rationality fails this test.

Neuroscientists and evolutionists have dug deeper into the origins of such seemingly 'irrational' behavior. The human brain has three quasi-independent subsystems with different functions that evolved at different times. Roughly speaking, the 'reptilian' part of the brain is responsible for many automatic and instinctual behaviors, the limbic system is responsible for emotions and related behaviors, and the more recently evolved neo-cortex is responsible for logic, abstract thought and planning for the future. People use different parts of the brain to make different types of decisions, and it is possible to frame a decision in such a way that it elicits a different response initiated in a different part of the brain [37]. Furthermore, "continuous exposure to fixed cultural norms (e.g., religious doctrines, political ideologies and disciplinary paradigms) literally helps to shape the brain's synaptic circuitry in quasi-fixed patterns that reflect and embed those experiences" which leads people to reject information that does not conform to their preexisting beliefs [38]. In fact, certainty appears to be more of an emotional state than the result of rational thought [39]. This helps explain surveys that show higher levels of education correlate with greater belief in anthropogenic climate change in all groups in the US except Republicans, where the inverse is true [40]; and that conservative white males, particularly those with high self-reported understanding of global warming, are more likely to deny anthropogenic climate change than other groups [41].

\subsection{Are People Purely Self-Interested?}

Convincing challenges to the notion of perfect selfinterest come from a wide variety of fields, including anthropology, mathematical biology, behavioral economics, neuroscience, epidemiology and evolution. Increasing evidence suggests that symbiotic cooperation has played a critical role in major evolutionary transitions, including the emergence of eukaryotes from cooperating groups of prokaryotes and multicellular life from cooperating groups of unicellular organisms $[42,43]$. Cooperation and concern for others is ubiquitous in humans and likely the major factor contributing to humanity's success [44-47]. Historically, economists used the theory of natural selection to support their assumption of self-interest, arguing that individuals who sacrificed their own fitness to help others would be out-competed by selfish individuals, thus purging altruism from the gene pool. However, mathematical biology has confirmed at least five different paths through which cooperation can evolve: direct reciprocity, indirect reciprocity, kin-selection, spatial proximity, and group selection. The fact that all five occur in humans makes us 'Super Cooperators' [45]. Anthropologists have empirically tested various theories of cooperation in modern communities, finding significant support for them [48], while evolutionists have tested their theories of cooperation against random samples from the anthropological literature, again finding significant support [49].

Perhaps the most interesting path to cooperation is group selection, or more accurately multi-level selection: groups with more altruistic individuals have greater reproductive success than those with more 
selfish individuals, even though within a given group, selfish individuals may be more fit [44, 45, 49-51]. This results in a population that can exhibit a wide range of genetic pre-dispositions towards pro-social behavior, ranging from purely selfish to highly altruistic. Many cooperative species ranging from slime molds to guppies and humans are able to detect and punish cheaters and favor cooperators, which further promotes cooperation [49, 52]. The need to identify cheaters and cooperators may in fact have played an important role in the evolution of human intelligence $[45,53]$.

In humans, the genetic capacity for cooperation has been supplemented by culture in a co-evolutionary process. Behavioral economists have devised a series of games that show that people will sacrifice their own welfare to help others even in anonymous settings, and will also sacrifice their own welfare in order to punish selfish individuals. Such punishment appears to be a social mechanism for promoting cooperation, and is thus known as altruistic punishment $[54,55]$. Mathematical models show that altruistic punishment, including the punishment of non-punishers, greatly facilitates the emergence of cooperation and is often built into cultural norms [48, 56]. As a result, different cultures exhibit different degrees of cooperation [45,57].

Another interesting finding is that cooperative species as varied as the prokaryote Myxococcus xanthus [58] and the eukaryote Dictostelium discoideum [52] cooperate when resources are scarce, but not when they are relatively abundant. This raises the interesting possibility that our competitive market economy is only viable in the presence of fossil fuels, which unleashed a new era of unprecedented resource abundance.

Confirming the biogenetic component of cooperation, neuroscientists have drawn attention to the neurotransmitter oxytocin and its kin, which are found in all animals from fish to mammals. Oxytocin serves as a hormone that stimulates birth contractions in mothers, and as a neurotransmitter that induces a strong feeling of bonding. When people engage in cooperative activities, their oxytocin levels increase, and administering aerosolized oxytocin increases the likelihood of cooperation in experimental games [59, 60]. Oxytocin is also stimulated by sexual activity, and induces sensations of well-being [61]. Perhaps blood oxytocin levels are a more accurate measure of utility than consumption!

Humans are capable of developing institutions that lead primarily selfish individuals to cooperate, or primarily cooperative individuals to be selfish $[22,62-$ 65]. One particularly disturbing finding is that monetary exchange may actually reduce cooperation by crowding out intrinsic motivations $[66,67]$, and simply priming people to think about money may make them more self-interested [68].

A final challenge to the assumption of perfect selfinterest is the compelling study by epidemiologists
Wilkinson and Pickett. Their research found that individuals in unequal societies experience higher levels of social and health problems then individuals in more equal societies, regardless of overall levels of income. In fact, wealthy individuals may be worse off in unequal societies than lower income individuals in more equal societies [69]. Humans appear to have an innate concern for fairness [70].

Integrating these insights into economic analysis has profound impacts. Many of the most serious problems faced by society today, ranging from climate change to developing green technologies, can be modeled as prisoners' dilemmas, which are best solved through cooperation $[45,71]$. If people evolved to be highly cooperative, if different economic institutions elicit different degrees of cooperation, and if markets can elicit selfish behavior, then it becomes obvious that we must explore a variety of allocative mechanisms in addition to markets $[22,72]$, such as strategies based on shared production and common ownership [71, 73-77]. If people are inherently social, then we must question the methodological individualism that underlies most microeconomic analysis. If people care about fairness and equality, then just distribution may be more important than Pareto efficiency.

\subsection{Are People Insatiable?}

The assumption of insatiability also fails to stand up to the scientific evidence. Perhaps the most obvious evidence comes from anthropology. Humans were nomadic hunter-gatherers for at least $95 \%$ of their history. As hunting and gathering activities depleted food supplies, tribes were forced to seek out new food sources, often far away. Those who attempted to accumulate more than they could carry would starve [78], so it is hard to envision an evolutionary advantage to insatiability. Nomadic societies were also highly egalitarian, and frequently punished individuals who took too large a share of available resources [49].

Why then are people in general so willing to consume more? Chilean economist Max-Neef suggests that people might believe (perhaps convinced by advertisers) that consuming a certain product will satisfy their need for freedom, affection, participation, leisure and so on. When consuming the product fails to satisfy, they may mistakenly believe that they simply have not consumed enough, leading to a feeling of insatiability [79]. Another problem arises with positional goods, consumed to confer status. Status is a relative concept, and if everyone's consumption level increases equally, then status is unchanged even as environmental impacts worsen [80]. Furthermore, as the rich increase their consumption of status goods, everyone else will feel worse off, and people may make important sacrifices of their own well-being in other areas in order to maintain their status [81-84]. Humans are other-regarding in envy as well as fairness. 
This evidence suggests that beyond a certain point, ever-increasing consumption, especially of positional goods, may provide few benefits for society, while imposing serious costs.

\subsection{Is the Science of Human Behavior Affecting Mainstream and Orthodox Economics?}

Economists at the edge of the mainstream (including many not cited above) have conducted much of the research on human behavior that challenges rationality, self-interest and satiability, with results frequently published in mainstream journals and taught in graduate programs. By these criteria, consilience is underway.

However, while an increasing number of undergraduate textbooks mention behavioral economics, it has yet to change orthodox economics in any meaningful way. Perhaps the most damning evidence here is the consistently replicated research showing that relative to the general population, people who study economics on average behave less cooperatively [85, 86]; prioritize profit maximization over fairness [87]; are more corrupt [88]; and are more likely to free ride [89]. Some of the differences are based on preselection (i.e. more selfish people are likely to study economics) but some are based on indoctrination [90]; in either case this does not bode well for consilience with the behavioral sciences. On the other hand, Bowles' [91] textbook accepts the science of human behavior and evolution as core principles, and may foreshadow a fundamental change in orthodox economics.

From the perspective of sustainability, consilience matters most when the resulting insights are incorporated into policy recommendations. Gowdy and Erickson (2005) argue that despite the fact that "neoclassical theorists have by and large abandoned economic man ...the policy recommendations of economists are still based on these outdated representations of human behavior...(and continue) to offer bad advice in dealing with some of the most pressing environmental and social issues faced in the twentyfirst century". Gintis [92] concurs that "environmental policies are generally based on a model of the human actor taken from neoclassical economic theory". Focusing specifically on the problems of positional goods, but equally relevant to other insights from the science of human behavior, Frank [93] asks "why does the economics profession take no account of these concerns when formulating economic policy recommendations?", and asserts that none of the responses provide by his colleagues bear scrutiny.

One reason that many economists fail to accept the insights from behavioral economics is the assertion that choice behavior is equivalent to welfare by definition, in which case it simply does not matter how or why people make particular choices. From this libertarian perspective, if we cannot make objective, interpersonal comparisons of utility, then the only objective goal is free choice (e.g. [29, 30]).

However, when economists argue for the satisfaction of subjective preferences as a central goal of economics, they fail to point out that markets weight preferences by purchasing power. Many of the problems central to sustainability concern the allocation of society's shared inheritance from nature. It is hardly value-neutral or objective to assert that we should allocate based on the principle of one dollar, one vote rather than one person, one vote, particularly if people care about fairness. Markets assign a weight of zero to the preferences of the destitute, and systematically allocate resources towards the wealthy. This is particularly troubling for resources that are essential and non-substitutable. Take food as an example. When the prices of grain more than doubled during the food crisis of 2007 to 2008 , rich countries such as the USA saw negligible change in consumption; the price of wheat tripled, yet consumption actually increased [94]. The poorest countries in contrast saw a dramatic surge in hunger and malnutrition [95]. Unquestionably, monetary value is maximized by allocating food to an overfed rich person willing to pay a high price rather than a malnourished and destitute family who can afford to pay almost nothing, but it is difficult to accept that this this is somehow optimal, efficient or utility maximizing. In fact, markets arguably allocate the marginal calorie to those who gained the least additional utility from its consumption [96]. The refusal of orthodox economics to make interpersonal comparisons of utility is so extreme however that mainstream textbooks essentially deny the distinction between wants and needs; to quote a typical textbook, "the law of demand puts the concept of basic human 'needs' to rest, at least as an analytical concept" ([97] p. 259). Denying physiological needs is denying basic science.

If I prefer oranges and you prefer apples, it may be impossible to determine if the utility I receive from oranges exceeds what you receive from apples, and allocation based on willingness to pay seems perfectly reasonable. However, to whom society decides to allocate resources required to satisfy physiological necessities is an ethical issue, not a question of preferences [98, 99]. This is especially true if those resources are a gift from nature.

While science can tell us much about the desirable ends of economic activity, which ends should be prioritized is ultimately an ethical question. Science may however be able to contribute insights into ethical issues. One hypothesis is that ethics is the result of gene-culture evolution designed to promote human cooperation, and hence the survival of the species. Jot down a list of five ethical behaviors and five unethical behaviors. You are likely to find that ethical behaviors put the group ahead of the individual, while unethical behavior puts the individual ahead of the group. Most religions similarly call for putting the group ahead of the individual [50]. Consilience with either the 
sciences or humanities would force economists to reconsider the goal of maximizing monetary value, particularly for essential resources.

\section{What Do the Physical and Life Sciences Tell Us About Scarce Resources?}

Consilience with the social sciences and humanities would force mainstream economics to reconsider what is desirable; consilience with the physical and life sciences would force it to reconsider what is possible. Conventional economics emerged at a time when natural resources were vast relative to human demands. The recently unleashed power of fossil fuels provided access to previously unavailable mineral resources and unprecedented quantities of renewable resources. Surplus output allowed society to allocate more resources towards science, and technological advances further enhanced humanity's resource base [100]. Economists came to assume that technology could always find a substitute for any given resource, to the point that they could safely ignore natural resources and focus entirely on capital and labor as the scarce means of production [101]. When economists again began to occasionally incorporate natural resources into their production functions in the 1970s, raw materials, capital and labor were treated as substitutes, as though one could make more bread from the same flour by adding more cooks and ovens [102-105]. Economists largely treated technology as manna from heaven, and virtually ignored the importance of cheap and abundant energy [106]. The power of fossil fuels however has allowed us to deplete natural capital stocks and increase waste emissions to levels that diminish the ecosystem's capacity to reproduce and to sustain critical functions. Economics can no longer ignore the laws of physics and ecology and the natural resource base on which society and the economy depend $[9,18,107]$.

\subsection{The Laws of Physics}

From the laws of physics we know that it is impossible to create something from nothing. All economic products result from the transformation of raw materials provided by nature. Furthermore, it is impossible to create nothing from something. All human made products break down, wear out and eventually fall apart, returning to the environment as waste. The extraction of raw materials from nature and the return of disordered waste are known as throughput. Simply maintaining existing capital stocks in the face of entropy requires continuous flows of throughput [108].

We also know from physics that the transformation of raw material inputs into economic products and waste requires low entropy energy, irreversibly converted through use into high entropy waste. Recycling energy without net energy loss is impossible [18,
109]. Finite stocks of fossil fuels account for nearly $90 \%$ of all energy used for economic production. We can use fossil fuels almost as fast as we like, but once used they are gone forever. New technologies have recently helped increase gross oil production, but with increasingly high energy costs per new barrel extracted, hence lower net energy and higher greenhouse gas emissions per barrel $[110,111]$. The renewable alternatives to fossil fuel are available in vast quantities, but most are highly diffuse, difficult to capture, transport and store, and flow at a fixed rate over time $[107,112]$. Sustainability demands that we deplete fossil fuel stocks no faster than we master the technologies required to bring alternative energy sources on line [108].

Economists must account for at least three distinct categories of factors of production, that are essentially complements, not substitutes, and that have different characteristics: raw materials, capital, and energy. Raw materials-which Aristotle called material cause and Georgescu-Roegen (1971) dubbed stock-flow resources - are physically transformed into economic products at a rate we choose, and use equals depletion. Capital and labor-which Aristotle called efficient cause and Georgescu-Roegen (1971) dubbed fund-service resources-transform raw materials into products that benefit humans at a given rate over time. Fund-services are not used up in the act of production, but rather are worn out and must be maintained. Fund-services require energy, such as fossil fuels, food or sunshine. As an example, a bakery requires flour, cooks, ovens and energy (food for the cooks, electricity for the ovens). Labor and capital, both fund-services, can substitute for each other, but are complements to flour and energy. A more efficient stove uses less energy, which could be construed as substitution at the margin, but once maximum efficiency has been achieved, no additional substitution is possible.

Finally, the most basic laws of physics and mathematics tell us that exponential increases in efficiency or exponential growth of any physical subsystem of a finite system can at best be transient phenomena [113]. One dollar invested in the year 0 at $6 \%$ interest would now have the same value as a ball of gold (at $\$ 1300$ an ounce) filling our solar system to the orbit of Pluto. The economy is a physical system, and cannot grow indefinitely.

\subsection{The Laws of Ecology}

The laws of ecology are almost certainly more tightly binding on economic activity than the laws of physics, though often far less understood. Many of the raw materials (stock-flow resources) physically transformed into economic products alternatively serve as the structural building blocks of ecosystems (funds that generate a service). Society can largely determine how fast to deplete available raw material stocks, such as 
trees in a forest. A particular configuration of ecosystem structure creates an ecosystem fund that generates a flux of services over time. The ecosystem fund is not physically transformed into the services it provides (e.g. a forested watershed is not transformed into flood regulation), but humans have little direct control over the rate at which these services are provided (a given hectare of forest can absorb only so much water per day). When ecosystem structure is removed and waste returned, often in novel forms to which ecosystems have not had an opportunity to adapt, ecosystem functions are affected: remove the trees or kill them with acid rain, and rain water rapidly flows over compacted soil into the adjacent river, causing flooding downstream. Many of these services are essential to sustaining life, including the capacity for ecosystems to regenerate [114, 115].

Ecosystems exhibit the non-linearity, positive and negative feedback loops, surprises and emergent behavior characteristic of complex systems [116]. They are also poorly understood, so we rarely know in advance the long (or even short) term impacts of our activities [117, 118]. Many ecosystem services are characterized by critical thresholds, beyond which they will flip into entirely different states, potentially far less amenable to the survival of humans and other species, and this may hold true for the global ecosystem as well. In most cases, we do not know where thresholds lie, nor do we know precisely what will happen if we exceed them [119, 120].

One of the major challenges in economics is to determine how much ecosystem structure should be converted into economic products, and how much left intact to generate ecosystem services. Two basic laws apply. First, humans cannot degrade or deplete any element of ecosystem structure (e.g. fish, forests, or fresh water) faster than it can regenerate without eventually crossing some threshold beyond which that component of the structure is gone, or else the ecosystem itself crosses an irreversible threshold, with often unpredictable but potentially catastrophic results. Enough structure must be left intact to maintain the flux of ecosystem services upon which humans and other species depend. Second, humans cannot emit waste into any finite system at rates greater than it is absorbed, or else waste stocks will accumulate, eventually harming humans and/or the ecosystem in potentially catastrophic ways. Unfortunately, failure to acknowledge the central importance of the life sciences to the field of economics has led us to surpass these limits [121]. It is now essential to reduce resource extraction below regeneration rates and waste emissions below absorption rates until stocks are restored to levels compatible with ecosystem resilience and the continued provision of ecosystem services. The longer we take to accept ecological limits to economic production, the greater the reductions required.

\subsection{Are the Sciences of Physics and Ecology Affecting} Mainstream and Orthodox Economics?

To achieve consilience with the physical and ecological sciences, economists must place energy, natural resources and waste at the core of their discipline, and distinguish between fund-service (labor, capital, ecosystems) and stock flow (raw materials) resources. Economists must recognize that converting ecosystem structure into economic products and emitting wastes inevitably degrades ecosystem functions and accept the urgent need to limit throughput to levels that do not threaten life support functions of ecosystems. The implications of these changes for sustainability are obvious, but do not stop there. One reason that economists pay little attention to distribution is that their models show that factors of production (including labor) are compensated according to their marginal product, which is considered fair. Including either natural resources or energy in economic production functions reveals that factors of production (e.g. labor and capital) are not awarded according to their marginal product [122-124], which would force economists to pay more attention to distribution. Acknowledging that virtually all economic activity degrades ecosystem services inevitably leaving some individuals worse off would force economists to abandon the criterion of Pareto efficiency.

An increasing number of economists are acknowledging that energy is an essential and non-substitutable factor of production $[18,123,125-127]$, but many simultaneously acknowledge that "[v]irtually all of modern economic growth theory assumes that GDP growth per capita is driven by technological progress and capital investment, including knowledge investment" and "does not take into account energy availability or prices" [122]. Similarly, many economists recognize that nature provides essential and nonsubstitutable benefits to humans while stressing that mainstream economists assume endless substitutability $[19,96,128-130]$. The emerging field of degrowth economics recognizes that the current level of economic activity already overwhelms planetary boundaries and calls for economic contraction in the aggregate to create ecological space for economic growth in the poorest countries. Again however, these economists almost inevitably distinguish themselves from the mainstream, where the goal of endless growth is considered the norm [131-134].

In the second update to Barnett and Morse's [12] Scarcity and Growth, Simpson et al. [106] provide an excellent summary of neoclassical economists' treatment of natural resources, energy and the environment as it has evolved over time. They conclude (though do not necessarily agree) that "majority opinion is that even in relatively short periods-years, even months-substitution possibilities obviate resource scarcity" ([106] p. 6). The justification for this 
belief is that scarcity leads to a price increase that creates the incentives for substitution, efficiency, or developing new substitutes. Orthodox economists often view technology as manna from heaven, which allows economic growth to continue forever. For example, a classic article by Solow [135] shows technology continuously increasing the efficiency with which we use fossil fuels so that we can continue to produce just as much from ever smaller quantities. Economists at least recognize that many ecosystem goods and services are public goods that generate no price signal-a market failure that must be corrected before substitution is guaranteed. More modern growth models view technology as endogenous and also subject to numerous market failures, but in general still conclude that endless growth is possible as long as suitable policies ensure adequate investments in technology [136].

Of course, few economists are calling for continuous physical growth of the economy, but rather for producing more from less, arguing that "nobody can define a finite absolute minimum material input required to produce a unit of economic welfare" ([137] p. 12). However, just as one dollar grows exponentially in value to equal a ball of gold the size of the solar system, continuous exponential growth in economic welfare, however measured, is likely to be equally impossible, and would eventually lead to a state of relentless bliss.

Economics is a huge field, and undeniably a growing number of economists are integrating ecology and physics into their work, for example in the study of ecosystem services, natural resources and climate change [138-140]. What really matters however is the extent to which this translates into advice for policy makers and education for the next generation of economists. The standard proxy for the size of the economy, GDP, makes no adjustments for the depletion of raw materials or energy, yet most economists and politicians alike call for its continuous growth, in spite of its widely recognized flaws [141, 142]. College textbooks in mainstream economics largely ignore energy, and most focus entirely on labor and capital as factors of production. Some textbooks do mention natural resources, but invariably suggest that capital, labor and technology are substitutes. Even more advanced courses in natural resource and environmental economics generally assume unlimited substitutability between raw materials and capital and focus on continuous economic growth. Most mainstream economists focus on Pareto efficiency, ignoring the fact that the resource extraction, fossil fuel and waste emissions that are the unavoidable consequences of economic activity invariably have negative impacts on others.

\section{Implications of Consilience for the Field of Economics}

If economics achieved consilience with other sciences, it would be forced to completely rethink the problem of allocation both within and between generations.
How we should allocate depends on the desired ends, the physical characteristics and status (e.g. abundance or scarcity) of the available resources, human behavior and existing institutions. Some of these factors are dynamic to at least some extent, and as they change, so too must the institutions and mechanisms required for allocation.

\subsection{Physical Characteristics of Available Resources}

Before describing how true consilience would affect economics, it is necessary to describe two important characteristics of the available resources. The first is known as excludability in economic jargon. A resource is excludable if it is possible for one person or group to use it while denying access to others. Access to such resources can be rationed, which is necessary for markets to exist. When a resource is non-excludable, anyone who wants can use it, and rationing is impossible. Excludability is a policy variable that can be implemented to different degrees, though some resources, including many ecosystem services, are inherently non-excludable. It would for example be impossible to ration access to a stable climate or the ozone layer's ability to protect us from ultraviolet radiation.

Rivalry is another important characteristic. A resource is rival if use by one person leaves less for others to use. All stock-flow resources are rival. For example, if one person cuts down a tree to build a house, that tree is no longer available for others to use. Some fund-service resources are also rival. For example, the more of the waste absorption capacity for greenhouse gas emissions used by the USA, the less is available for other nations. When global emissions exceed absorption capacity, they accumulate as harmful atmospheric stocks. A resource is non-rival if use by one person does not leave less for others to use. If a forested watershed prevents damaging floods, landslides and erosion, the benefits captured by one person living in the regions affected do not leave less for others to use. Only fund-services can be non-rival.

Non-rival resources are not scarce in an economic sense and there is therefore no need to compete for them. In economic terms, abundant, rival resources are similar to non-rival resources. For example, a towel on a beach or a car on the road leaves less space available for another towel or another car, which is the definition of rivalry. However, when available space on the beach or road is abundant, there is no competition for use, and the resource appears to be non-rival. Road tolls, beach entrance fees or other policies can ensure that spaces remain abundant. This has led many economists to argue that rivalry is a policy variable. In fact, rivalry is a physical characteristic that cannot be affected by policy [9]. No policy can change the fact that burning a barrel of oil leaves less for others, or the fact that additional people adopting a technology for 
energy efficiency does not reduce its effectiveness for those who adopted it first. Information is more than just non-rival: it actually improves with use [143]. Information is also essential for all economic production and must play an important role in addressing our current ecological crises.

\subsection{The 'Laws' of Economics}

Modern economics emerged at the end of the 18th century, when natural resources were relatively abundant and per capita consumption of human made goods and services a tiny fraction of what it is today (Delong [144] estimates that real global GDP per capita has increased more than 30 fold since 1800). Increasing the output of human made products was arguably the best way to improve human welfare, and markets an effective way to achieve this goal. Most economists therefore focused on market allocation. The market price mechanism allocates scarce resources towards the products that add the most monetary value then rations those products towards the consumers willing to pay the most for them. The rule for achieving this outcome is to keep producing or consuming until rising marginal costs equal diminishing marginal benefits. The logic is straightforward: when marginal benefits exceed marginal costs then increasing consumption of a single commodity or of economic production as a whole increases total utility. However, if marginal costs exceed marginal benefits, then additional consumption makes us worse off. Diminishing marginal utility, rising marginal costs, and the equimarginal principle of optimization (i.e. halting consumption when $\mathrm{MB}=\mathrm{MC}$ ) are treated as basic laws of mainstream economics.

Mainstream economics generally focuses on diminishing marginal utility for individual commodities: the first 2000 calories you consume per day provide far greater benefits than the next 2000. The same rule applies however for aggregate consumption. In general, people spend their first units of income on basic necessities, such as food, water, shelter and clothing. As we earn more income, we buy increasingly less essential commodities with increasingly smaller contributions to our well-being. This means there are diminishing marginal benefits to increasing consumption, and hence to economic growth. The marginal costs of economic growth however are rising. As individuals in a competitive market, we pay the same nominal price for each additional unit we consume. However, when we work to produce things or earn money, we sacrifice the opportunity to engage in other activities we might enjoy more. As we work longer hours to earn more money, we must sacrifice increasingly desirable alternative activities, so the real cost of consumption rises. At the same time, if we accept the laws of physics and ecology, for any given technology, increasing economic production requires the conversion of larger quantities of raw materials and energy into economic products and waste, sacrificing more ecosystem services. Logically, society will sacrifice the least important ecosystems and services first, and must therefore sacrifice increasingly important services with increasing production. Eventually, the rising ecological costs of economic growth will exceed the diminishing marginal benefits, and growth becomes uneconomic, meaning that it makes us worse off [145]. New technologies may allow us to produce more from less, but there are limits to efficiency improvements, and the inexorable laws of exponential growth will ultimately take over. Furthermore, efficiency improvements often result in greater resource use, not less, and the same is true for economic growth [146].

Eventually, as we convert more ecosystem structure into economic products and return more waste, we run the risk of crossing critical ecological thresholds and imposing unacceptable ecological costs on society. When we cross a threshold, a marginal change in activity leads to a non-marginal change in outcome. If the threshold involved leads to the loss of an entire species or ecosystem, we must compare the marginal benefits from the activity with the total value of the species or ecosystem that is lost into the indefinite future [147]. Given the law of ecology that everything is connected to everything else [148], the total value may be unpredictable in advance, and may not be realized for decades or even centuries [149]. Balancing marginal costs with marginal benefits is no longer appropriate.

The central focus of an economics consilient with laws of ecology and physics should no longer be about maximizing the monetary value of market goods and services. Rather, the first priority should be to ensure that economic activity does not lead us to cross critical ecological thresholds, ranging from nitrogen emissions to biodiversity loss and climate change. With current technologies, this may be very difficult. For example, Rockstrom et al. [2] estimate that nitrogen emissions must be reduced by $70 \%$ if we are to avoid such thresholds, while greenhouse gas emissions must be reduced by at least $80 \%$ [150]. With current technologies it is not obvious that we can reduce emissions by that much and still feed 7 billion people. Major investments in research and development in agriculture and clean energy will be required. Even when safely distant from critical thresholds, economists should focus on ensuring that the marginal ecological costs of economic activity do not exceed the marginal benefits, even though direct comparison of the costs and benefits may be difficult or impossible.

\subsection{Resource Characteristics and Allocation}

Markets are unlikely to be a suitable mechanism for achieving these economic goals. In the absence of excludability, anyone who wants can consume a resource 
whether or not they pay, and hence are unlikely to voluntarily pay in a competitive market or a in a culture that promotes self-interest. Ecosystem structure and mineral resources are typically excludable under existing institutions, and can easily be converted into market commodities. However, the ecosystem services lost from removing structure and emitting waste are frequently non-excludable. Markets do not compensate for their provision or penalize for their loss. The result is over consumption, under-provision and degradation. This dynamic explains anthropogenic climate change, land use conversion, biodiversity loss, and most of the other serious problems currently faced by society.

One solution is to make the resource excludable so that it becomes possible to ration access. It is impossible to make services such as climate regulation, disturbance regulation or protection from UV radiation excludable, but it is generally possible to regulate or make excludable the activities that destroy these services. However, making something excludable requires collective action via social institutions; it is a prerequisite for market allocation, and not the result of markets. If sustainability is a goal, then society must step in to regulate access to ecosystem structure and waste absorption capacity to ensure the adequate provision of ecosystem services. Mainstream economists often argue that simply establishing tradable private property rights will automatically lead to efficient allocation, so who receives those rights is relatively unimportant $[151,152]$. However, as we saw above with the case of food, market allocation often forces those with the greatest level of physiological need for a resource to reduce consumption the most. If we limit land use change, biodiversity loss, freshwater and nitrogen to ecologically sustainable levels, food prices will likely skyrocket and the poor will starve, which is not socially sustainable. If humans do indeed care about fairness and the well-being of others, then price-rationing of essential resources-especially those freely provided by nature-is inappropriate. Deliberative democratic processes give equal weight to everyone's preferences, while markets weight preferences by purchasing power. Which of these approaches to use is about the distribution of power. Furthermore, ubiquitous externalities rule out Pareto efficiency as a useful criterion, since virtually all economic activities have negative impacts on others.

But rationing access is not always a solution. Nonrival resources are not depleted through use, and rationing access therefore reduces benefits without affecting costs. Such resources are not scarce in an economic sense, as there is no need to compete for them once they exist-though there is competition for any rival resources that might be required to produce or protect them. Markets are only efficient (i.e. able to balance marginal costs with marginal benefits) for resources that are rival. Paradoxically, the economic surplus (the monetary value of total benefits minus total costs) from non-rival resources is maximized at a price of zero where anyone who wants can consume the resource. This is especially true for clean technologies that replace polluting ones. However, at a price of zero, market supply is also zero. Economic systems must still allocate resources towards the production or protection of non-rival resources. Private property rights to non-rival resources, (e.g. patents) provide market incentives to supply them, but simultaneously reduce the economic surplus they generate. The appropriate allocation mechanism is some form of cooperative (e.g. publicly financed) provision that rewards innovators while making their innovations freely available $[71,153]$.

Many of society's most important resources, ranging from global climate stability and clean energy technologies (information) to biodiversity and critical ecosystem services, are non-rival and inherently nonscarce, challenging the very definition of economics. Most of these resources are also inherently nonexcludable so that rationing access is also impossible. However, global society has been strengthening intellectual property rights for decades, using prices to ration access to many of the technologies required to solve our global problems [154]. For example, if we develop a clean, efficient, decentralized form of solar energy, no matter how much solar energy one country captures, there will be no less for others, and the technology itself is likely to improve through use. Patenting the technology and charging for it will reduce use and hence the potential for reducing climate change [71].

If people were inherently self-interested and competitive, as typically modeled by orthodox economists, then we would be forced to rely on economic institutions that channel that behavior towards the common good, such as markets. Behavioral sciences however show that humans are capable of cooperation, and can build institutions that enhance our innate propensity for pro-social behavior. As discussed above, markets may actually undermine cooperation.

If economists hope to contribute to sustainability science, they must take a scientific approach to economics that builds on insights from the physical, life, and social sciences. Objective physical characteristics of resources, not ideology, determine whether competitive or cooperative allocation is most efficient. Table 1 briefly describes potentially suitable mechanisms for allocating different types of resources. While versions of this table are fairly standard in the economic literature, most economists treat problems resulting from non-excludability and non-rivalry as market failures, externalities that should be internalized through market prices. An economics that was more consilient with advances in other fields would instead recognize that economic activity unavoidably degrades the environment, environmental degradation is one of the greatest threats to human welfare, and most environmental problems take the form of prisoners' dilemmas that can only be solved through 
cooperation. Economics should therefore strive to develop the cooperative institutions required to solve these problems, and abandon its obsession with private property and markets.

Table 1. Resource Characteristics and their Implications for Allocation.

\begin{tabular}{|c|c|c|}
\hline & Excludable & Non-excludable \\
\hline Rival and scarce & $\begin{array}{l}\text { Potential market goods, e.g food, oil, } \\
\text { land, consumer goods, but with } \\
\text { inevitable negative externalities, ruling } \\
\text { out Pareto efficiency as a decision tool. } \\
\text { Rationing is desirable, but price } \\
\text { rationing of essential resources is } \\
\text { problematic. }\end{array}$ & $\begin{array}{l}\text { Open access regimes e.g. absorption } \\
\text { capacity for greenhouse gasses; } \\
\text { oceanic fisheries: rationing is } \\
\text { desirable, but requires cooperation and } \\
\text { collective action. }\end{array}$ \\
\hline $\begin{array}{l}\text { Rival and } \\
\text { abundant } \\
\text { (club or toll } \\
\text { goods) }\end{array}$ & $\begin{array}{l}\text { Club or Toll goods e.g. beaches, parks: } \\
\text { rationing desirable when scarcity is a } \\
\text { threat. }\end{array}$ & $\begin{array}{l}\text { Rationing is desirable when scarcity is } \\
\text { a threat, but requires cooperation and } \\
\text { collective action. }\end{array}$ \\
\hline Non-rival & $\begin{array}{l}\text { Tragedy of the non-commons e.g. } \\
\text { patented green technologies: } \\
\text { rationing undesirable. Open access is } \\
\text { more efficient, but requires } \\
\text { cooperation and collective action. }\end{array}$ & $\begin{array}{l}\text { Public goods/open access resources } \\
\text { e.g. climate regulation, flood } \\
\text { regulation, open source information: } \\
\text { rationing undesirable and impossible. } \\
\text { Cooperative provision is essential. }\end{array}$ \\
\hline
\end{tabular}

\subsection{Conclusions}

There is little question that the discipline of economics is in a rapid state of flux. Leading economists at the edge of the mainstream are undoubtedly incorporating ideas from the science of human behavior, physics and ecology, and these are slowly filtering down into the mainstream. Even ideas from decidedly non-mainstream fields such as ecological and biophysical economics are becoming more widely accepted. Consilience is occurring. Unfortunately, there is less evidence that the sciences are having much impact on the economic orthodoxy, which is widely taught to undergraduates, or on the advice given to policy makers. Perhaps this is to be expected however, as academic disciplines tend to evolve slowly.

At the same time however, the economic system is also in an extremely rapid state of flux, and its impacts on global ecosystems are unfolding at an unprecedented pace. Since the 1950s, the human population has more than doubled, the use of petroleum has nearly quadrupled, and economic activity has increased by a factor of fifteen. Ecological impacts have increased at the same pace [1]. Economists can no longer afford to ignore basic principles of ecology and physics. Solving these problems will require new economic institutions based on cooperation, and such institutions must be based on detailed knowledge of human behavior. A few decades ago, stocks were long-term investments held for years. Today, they are held for seconds $[155,156]$. Foreign currency transactions used to be strictly regulated. Today, annual transactions are more than twenty times global GDP [157]. In complex systems, such rapid and powerful changes can have profound impacts, such as the financial crisis of 2008, which caught most economists completely unaware. The financial crisis undoubtedly pales in comparison to the more slowly unwinding ecological crises we now face. Economists can no longer afford to ignore the fact that the ecological-economic system is a complex, adaptive system subject to surprise and emergent behavior.

Economic theory must evolve at least as fast as the economic system if it is to help society face 21st century challenges. When unfolding events falsify theories from mainstream and orthodox economics, those theories must be abandoned. We cannot passively await progress at the edge of economics to filter through to practitioners and textbooks over coming decades. Consilience must be aggressively pursued as a core principle of economic theory.

\section{Acknowledgments}

I would like to thank the Vermont Agricultural Experiment Station Hatch Program for the funding necessary to write this article. I also wish to acknowledge the extremely useful comments made by anonymous peer reviewers. 


\section{References}

[1] Steffen W, Grinevald J, Crutzen P, McNeill J. The Anthropocene: Conceptual and historical perspectives. Philosophical Transactions of the Royal Society A: Mathematical, Physical and Engineering Sciences. 2011;369(1938):842-867.

[2] Rockstrom J, Steffen W, Noone K, Persson A, Chapin FS, Lambin EF, et al. A safe operating space for humanity. Nature. 2009;461(7263):472-475.

[3] Kates RW, Clark WC, Corell R, Hall JM, Jaeger CC, Lowe I, et al. Sustainability Science. Science. 2001;292(5517):641-642.

[4] Reid WV, Chen D, Goldfarb L, Hackmann H, Lee YT, Mokhele K, et al. Earth System Science for Global Sustainability: Grand Challenges. Science. 2010;330(6006):916-917.

[5] Gintis H, Bowles S, Boyd R, Fehr E. Moral Sentiments and Material Interests: Origins, Evidence and Consequences. In: Gintis $\mathrm{H}$, Bowles S, Boyd R, Fehr E, editors. Moral Sentiments and Material Interests: The Foundations of Cooperation in Economic Life. Cambridge, MA, USA: MIT Press; 2005. pp. 3-40.

[6] Wilson EO. Consilience: The Unity of Knowledge. New York, NY, USA: Knopf; 1998.

[7] Wilson DS. Consilience: Making contextual behavioral science part of the United Ivory Archipelago. Journal of Contextual Behavioral Science. 2012;1(1-2):39-42.

[8] Georgescu-Roegen N. Methods in Economic Science. Journal of Economic Issues. 1979;13(2): 317-328.

[9] Daly HE, Farley J. Ecological Economics: Principles and Applications. 2nd ed. Washington, DC, USA: Island Press; 2010.

[10] Brown P. The Unfinished Journey of Ecological Economics: Toward an Ethic of Ecological Citizenship. In: Farley J, Malghan D, Goodland R, editors. Beyond Uneconomic Growth: Solving Society's Most Pressing Ecological Economic Crises. London, UK: Edward Elgar; Forthcoming.

[11] Beckerman W. Economists, Scientists, and Environmental Catastrophe. Oxford Economic Papers. 1972;24(3):327-344.

[12] Barnett H, Morse C. Scarcity and Growth: The Economics of Natural Resource Availability. Baltimore, MD, USA: John Hopkins University Press; 1963.

[13] Simon J. The Ultimate Resource 2. Princeton, NJ, USA: Princeton University Press; 1996.

[14] Mann C. What If We Never Run Out of Oil? The Atlantic. 2013. Available from: http://www.the atlantic.com/magazine/archive/2013/05/what-ifwe-never-run-out-of-oil/309294/.

[15] Costanza R, Cumberland J, Daly HE, Goodland R, Norgaard RB. An Introduction to Ecological Economics. Boca Raton, FL, USA: International Society for Ecological Economics and St. Lucie
Press; 1997.

[16] Gowdy JM, Carbonell AF. Toward consilience between biology and economics: The contribution of Ecological Economics. Ecological Economics. 1999;29(3):337-348.

[17] Gowdy J, Erickson J. The approach of ecological economics. Cambridge Journal of Economics. 2005;29(2):207-222.

[18] Hall CAS, Klitgaard KA. Energy and the Wealth of Nations. New York, NY, USA: Springer; 2011.

[19] Spash CL. The shallow or the deep ecological economics movement? Ecological Economics. 2013;93(0):351-362.

[20] Weintraub ER. Neoclassical Economics. The Concise Encyclopedia of Economics. Library of Economics and Liberty; 1993. Available from: http://www.econlib.org/library/Enc1/Neoclassical Economics.html.

[21] Arnsperger C, Varoufakis Y. What Is Neoclassical Economics? The three axioms responsible for its theoretical oeuvre, practical irrelevance and, thus, discursive power. Post-autistic Economics Review. 2006(38):2-12.

[22] Vatn A. Institutions and the Environment. Northhampton, MA, USA: Edward Elgar; 2005.

[23] Hodgson GM. Evolutionary and Institutional Economics as the New Mainstream. Evolutionary and Institutional Economics Review. 2007;4(1):7-25.

[24] Colander D, Holt RPF, Rosser Jr. JB. The Changing Face of Mainstream Economics. Review of Political Economy. 2004;16(4):485-499.

[25] Samuelson P. Foreword. In: Saunders P, Walstad $W$, editors. The Principles of Economics Course: A Handbook for Instructors. New York, NY, USA: McGraw-Hill Publishing; 1990. p. VII.

[26] O'Neill JF. The Market: Ethics, Knowledge and Politics. London, UK: Routledge; 1998.

[27] Mill JS. Utilitarianism. 4th ed. London, UK: Longmans, Green, Reader, and Dyer; 1871.

[28] Samuelson P. Consumption Theory in Terms of Revealed Preference. Economica. 1948;15(60): 243-253.

[29] Gul F, Pesendorfer W. The Case for Mindless Economics. In: Caplin A, Schottter A, editors. The Foundations of Positive and Normative Economics. Oxford, UK: Oxford University Press; 2008.

[30] Stigler G], Becker GS. De Gustibus Non Est Disputandum. The American Economic Review. 1977;67(2):76-90.

[31] Posner RA. Wealth Maximization Revisited. Notre Dame Journal of Law, Ethics and Public Policy. 1985;2:85-105.

[32] Simon HA. Rational Decision Making in Business Organizations. American Economic Review. 1979;69(4):493-513.

[33] Kahneman D, Tversky A. Choices, Values, and Frames. New York, NY, USA: Cambridge University Press, Russell Sage Foundation; 2000.

[34] Ariely D. Predictably Irrational. New York, NY, 
USA: Harper Collins; 2008.

[35] Thaler RH, Sunstein CR. Nudge: Improving decisions about health, wealth, and happiness. New Haven, CT, USA: Yale University Press; 2008.

[36] Friedman M. Essays in Positive Economics. Chicago, IL, USA: University of Chicago Press; 1953.

[37] Rosenbloom MH, Schmahmann JD, Price BH. The Functional Neuroanatomy of DecisionMaking. The Journal of Neuropsychiatry and Clinical Neurosciences. 2012;24:266-277.

[38] Rees W. Denying Herman Daly: Why Conventional Economics Will not Embrace the Daly Vision. In: Farley J, Malghan D, Goodland $\mathrm{R}$, editors. Herman Daly Festschrift (e-book): Encyclopedia of Earth. 2011. Available from: http://www.eoearth.org/article/Herman_Daly_Fe stschrift_\%28e-book\%29.

[39] Burton RA. On Being Certain-Believing You Are Right Even When You're Not. New York, NY, USA: St. Martin's Press; 2008.

[40] Pew Research Center for the People \& the Press. A Deeper Partisan Divide Over Global Warming. Washington, DC, USA: Pew Research Center; 2008.

[41] McCright AM, Dunlap RE. Cool dudes: The denial of climate change among conservative white males in the United States. Global Environmental Change. 2011;21(4):1163-1172.

[42] Maynard Smith JES. The Origins of Life: From the Birth of Life to the Origin of Language. New York, NY, USA: Oxford University Press; 1999.

[43] Margulis L. Origin of Eukaryotic Cells: Evidence and Research Implications for a Theory of the Origin and Evolution of Microbial, Plant, and Animal Cells on the Precambrian Earth. New Haven, CT, USA: Yale University Press; 1970.

[44] Wilson DS, Wilson EO. Rethinking the Theoretical Foundations of Sociobiology. The Quarterly Review of Biology. 2007;82(4):327-348.

[45] Nowak M, Highfield R. Super Cooperators: Altruism, Evolution, and Why We Need Each Other to Succeed. New York, NY, USA: Free Press (Simon Schuster); 2011.

[46] Gintis H, Bowles S, Boyd R, Fehr E, editors. Moral Sentiments and Material Interests: The Foundations of Cooperation in Economic Life. Cambridge, MA, USA: MIT Press; 2005.

[47] Wilson EO. The Social Conquest of Earth. New York, NY, USA: Liveright Publishing Corporation; 2012.

[48] Henrich J, Henrich N. Why Humans Cooperate: A Cultural and Evolutionary Explanation. New York, NY, USA: Oxford University Press; 2007.

[49] Sober E, Wilson DS. Unto Others: The Evolution and Psychology of Unselfish Behavior. Cambridge, MA, USA: Harvard University Press; 1998.

[50] Wilson DS. Evolution for everyone: How Darwin's theory can change the way we think about our lives. New York, NY, USA: Delacorte Press; 2007.
[51] Darwin C. The Descent of Man. London, UK: Penguin Classics; 2004.

[52] Hudson RE, Aukema JE, Rispe C, Roze D. Altruism, Cheating, and Anticheater Adaptations in Cellular Slime Molds. The American Naturalist. 2002;160(1):31-43.

[53] Cosmides L, Barrett HC, Tooby J. Adaptive specializations, social exchange, and the evolution of human intelligence. Proceedings of the National Academy of Sciences. 2010;107(2):9007-9014.

[54] Boyd R, Gintis H, Bowles S, Richerson PJ. The evolution of altruistic punishment. Proceedings of the National Academy of Sciences of the United States of America. 2003;100(6):3531-3535.

[55] Bowles S, Gintis H. The evolution of strong reciprocity: Cooperation in heterogeneous populations. Theoretical Population Biology. 2004;65(1):17-28.

[56] Boyd R, Richerson PJ. Punishment allows the evolution of cooperation (or anything else) in sizable groups. Ethology and Sociobiology. 1992;13(3):171-195.

[57] Henrich J, Boyd R, Bowles S, Camerer C, Fehr E, Gintis $\mathrm{H}$, et al. In search of Homo economicus: Behavioral experiments in 15 small-scale societies. American Economic Review. 2001;91(2):73-78.

[58] Velicer G, Stredwick K. Experimental social evolution with Myxococcus xanthus. Antonie van Leeuwenhoek. 2002;81(1):155-164.

[59] Kosfeld M, Heinrichs M, Zak PJ, Fischbacher U, Fehr E. Oxytocin increases trust in humans. Nature. 2005;435(7042):673-676.

[60] Zak PJ. The Neurobiology of Trust. Scientific American. 2008;298:88-95.

[61] Gordon I, Martin C, Feldman R, Leckman JF. Oxytocin and social motivation. Developmental Cognitive Neuroscience. 2011;1(4):471-493.

[62] Fischbacher U, Gächter S, Fehr E. Are people conditionally cooperative? Evidence from a public goods experiment. Economics Letters. 2001;71:397-404.

[63] Gachter S. Conditional Cooperation: Behavioral Regularities from the Lab and the Field and Their Policy Implications. In: Frey BS, Stutzer A, editors. Economics and psychology: A promising new cross-disciplinary field. Cambridge, MA, USA: MIT Press; 2007.

[64] Ostrom E. Governing the Commons: The Evolution of Institutions for Collective Action. Cambridge, UK: Cambridge University Press; 1990.

[65] Ostrom E, editor. The Drama of the Commons. Washington, DC, USA: National Academy Press; 2002.

[66] Frey BS, Jegen R. Motivation Crowding Theory. Journal of Economic Surveys. 2001;15(5): 589-611.

[67] Gneezy U, Rustichini A. Pay Enough Or Don't Pay At All. The Quarterly Journal of Economics. 2000;115(3):791-810.

[68] Vohs KD, Mead NL, Goode MR. The Psychological 
Consequences of Money. Science. 2006;314 (5802):1154-1156.

[69] Wilkinson R, Pickett K. The Spirit Level: Why Greater Equality Makes Societies Stronger. New York, NY, USA: Bloomsbury Press; 2009.

[70] Fehr E, Schmidt KM. A Theory Of Fairness, Competition, And Cooperation. The Quarterly Journal of Economics. 1999;114(3):817-868.

[71] Farley J, Perkins S. Economics of Information in a Green Economy. In: Robertson $\mathrm{R}$, editor. Building a Green Economy. East Lansing, MI, USA: Michigan State University Press; 2013.

[72] Bromley D. Environment and Economy: Property Rights and Public Policy. Oxford, UK: Blackwell; 1991.

[73] Barnes P, Costanza R, Hawken P, Orr D, Ostrom E, Umana A, et al. Creating an Earth Atmospheric Trust. Science. 2008;319(5864):724.

[74] Barnes P. Capitalism 3.0. A Guide to Reclaiming the Commons. San Francisco, CA, USA: BerrettKoehler Publishers; 2006.

[75] Benkler Y. Commons-Based Strategies and the Problems of Patents. Science. 2004;305(5687): 1110-1111.

[76] Raffensperger C, Weston B, Bollier D. Define and Develop a Law of the Ecological Commons for Present and Future Generations; 2009.

[77] Bollier D. Silent Theft: The Private Plunder of our Common Wealth. New York, NY, USA: Routledge; 2002.

[78] Gowdy J, editor. Limited Wants, Unlimited Means: A Reader on Hunter-Gatherer Economics and the Environment. Washington, DC, USA: Island Press; 1998.

[79] Max-Neef M. Development and Human needs. In: Ekins $P$, Max-Neef $M$, editors. Real-life Economics: Understanding Wealth Creation. London, UK: Routledge; 1992. pp. 197-213.

[80] Schor JB. Prices and quantities: Unsustainable consumption and the global economy. Ecological Economics. 2005;55(3):309-320.

[81] Frank R. Luxury Fever: Why Money Fails to Satisfy in an Era of Excess. New York, NY, USA: Free Press; 1999.

[82] Levine AS, Frank RH, Dijk O. Expenditure Cascades. 2010 Available at SSRN: http://dx.doi.org/10.2139/ssrn.1690612.

[83] Layard R. Happiness: Lessons from a New Science. New York, NY, USA: Penguin Press; 2005.

[84] Hirsch F. Social Limits to Growth. Cambridge, MA, USA: Harvard University Press; 1976.

[85] Bauman Y, Rose E. Selection or indoctrination: Why do economics students donate less than the rest? Journal of Economic Behavior \& Organization. 2011;79(3):318-327.

[86] Frank RH, Gilovich T, Regan DT. Does Studying Economics Inhibit Cooperation? Journal of Economic Perspectives. 1993;7(2):159-171.

[87] Cipriani GP, Lubian D, Zago A. Natural born economists? Journal of Economic Psychology. 2009;30(3):455-468.

[88] Frank B, Schulze GG. Does economics make citizens corrupt? Journal of Economic Behavior \& Organization. 2000;43(1):101-113.

[89] Marwell G, Ames RE. Economists free ride, does anyone else?: Experiments on the provision of public goods, IV. Journal of Public Economics. 1981;15(3):295-310.

[90] Kirchgässner G. (Why) are economists different? European Journal of Political Economy. 2005;21(3):543-562.

[91] Bowles S. Microeconomics: Behavior, Institutions and Evolution. Princeton, NY, USA: Princetion University Press; 2006.

[92] Gintis H. Beyond Homo economicus: Evidence from experimental economics. Ecological Economics. 2000;35(3):311-322.

[93] Frank RH. Positional Externalities Cause Large and Preventable Welfare Losses. American Economic Review. 2005;95(2):137-141.

[94] USDA. Wheat data. 2013. Available from: http://www.ers.usda.gov/data-products/wheatdata.aspx\#.U1b5kfl5OSq.

[95] FAO. The State of Food Insecurity in the World 2008. Rome, IT: FAO; 2008.

[96] Farley J. Ecosystem Services: The Economics Debate. Ecosystem Services. 2012;1(1):40-49.

[97] Sexton RL. Exploring Microeconomics: Instructor's edition. Mason, $\mathrm{OH}$, USA: Southwestern Cengage Learning; 2011.

[98] O'Neill J. Managing without Prices: The Monetary Valuation of Biodiversity. Ambio. 1997;26(8): 546-550.

[99] Spash CL. How much is that ecosystem in the window? The one with the biodiverse trail. Environmental Values. 2008;17(2):259-284.

[100] Beddoe R, Costanza R, Farley J, Garza E, Kent J, Kubiszewski I, et al. Overcoming Systemic Roadblocks to Sustainability: The evolutionary redesign of worldviews, institutions and technologies. Proceedings of the National Academy of Sciences. 2009;106(8):2483-2489.

[101] Farley J. Natural Capital. In: Anderson R, editor. Berkshire Encyclopedia of Sustainability: Great Barrington, MA, USA: Berkshire Publishing; 2012. pp. 264-267.

[102] Daly HE. Georgescu-Roegen versus Solow/Stiglitz. Ecological Economics. 1997;22(3):261-266.

[103] Daly HE. Georgescu-Roegen versus Solow/ Stiglitz-Reply. Ecological Economics. 1997;22(3): 271-273.

[104] Stiglitz JE. Georgescu-Roegen versus Solow/ Stiglitz. Ecological Economics. 1997;22(3):269270.

[105] Solow RM. Georgescu-Roegen versus Solow/ Stiglitz. Ecological Economics. 1997;22(3):267268.

[106] Simpson RD, Toman MA, Ayres RU, editors. 
Scarcity and Growth Revisited: Natural Resources and the Environment in the New Millenium. Washington, DC, USA: Resources for the Future; 2005.

[107] Georgescu-Roegen N. The Entropy Law and the Economic Process. Cambridge, MA, USA: Harvard University Press; 1971.

[108] Daly HE. Steady-State Economics: The Political Economy of Bio- physical Equilibrium and Moral Growth. San Francisco, CA, USA: W. H. Freeman and Co.; 1977.

[109] Georgescu-Roegen N. Energy and Economic Myths. Southern Economic Journal. 1975;41(3): 347-381.

[110] Gates ID, Larter SR. Energy efficiency and emissions intensity of SAGD. Fuel. 2014;115(0): 706-713.

[111] Hall CAS, Lambert JG, Balogh SB. EROI of different fuels and the implications for society. Energy Policy. 2014;64(0):141-152.

[112] Hall CAS, Cleveland CJ, Kaufmann R. Energy and Resource Quality. New York, NY, USA: Wiley Interscience; 1986.

[113] Hubbert MK. Exponential Growth as a Transient Phenomena in Human History. In: Daly $\mathrm{H}$, Townsend $\mathrm{K}$, editors. Valuing the Earth: Economics, Ecology, Ethics. Cambridge, MA, USA: MIT Press; 1993. p-. 113-125.

[114] Malghan D. A dimensionally consistent aggregation framework for biophysical metrics. Ecological Economics. 2011;70(5):900-909.

[115] Farley J, Costanza R. Payments for ecosystem services: From local to global. Ecological Economics. 2010;69(11):2060-2068.

[116] Meadows D. Thinking in Systems: A Primer. White River Junction, VT, USA: Chelsea Green; 2008.

[117] Millennium Ecosystem Assessment. Ecosystems and Human Well-being: Synthesis. Washington, DC, USA: Island Press; 2005.

[118] Faber MM, Proops JL, Manstetten R. Evolution, Time, Production and the Environment. New York, NY, USA: Springer-Verlag; 1998.

[119] Barnosky AD, Hadly EA, Bascompte J, Berlow EL, Brown JH, Fortelius M, et al. Approaching a state shift in Earth/'s biosphere. Nature. 2012; 486(7401):52-58.

[120] Muradian R. Ecological thresholds: A survey. Ecological Economics. 2001;38(1):7-24.

[121] Daly HE. Towards some operational principles for sustainable development. Ecological Economics. 1990;2(1):1-6.

[122] Ayres RU, van den Bergh JCJM, Lindenberger D, Warr B. The underestimated contribution of energy to economic growth. Structural Change and Economic Dynamics. 2013;27(0):79-88.

[123] Kümmel R. Why energy's economic weight is much larger than its cost share. Environmental Innovation and Societal Transitions. 2013;9(0):33-37.

[124] Daly H. How long can neoclassical economics ignore the contributions of Georgescu-Roegen? In: Mayumi K, Gowdy J, editors. Bioeconomics and Sustainability: Essays in Honor of Nicholas Georgescu-Roegen. Cheltenham, UK: Edward Elgar Publishing; 1999. pp. 13-24.

[125] Apergis N, Payne JE. Energy consumption and growth in South America: Evidence from a panel error correction model. Energy Economics. 2010;32(6):1421-1426.

[126] Ayres R, Warr B. The Economic Growth Engine: How Energy and Work Drive Material Prosperity. Northampton, MA, USA: Edward Elgar; 2009.

[127] Victor P. Managing Without Growth: Slower by Design, not Disaster. Cheltenham, UK: Edward Elgar Publishing; 2008.

[128] Ekins P, Simon S, Deutsch L, Folke C, De Groot R. A framework for the practical application of the concepts of critical natural capital and strong sustainability. Ecological Economics. 2003;44(23): 165-185.

[129] Neumayer E. Weak Versus Strong Sustainability: Exploring the limits of two opposing paradigms. Cheltenham, UK: Edward Elgar Publishing; 2003.

[130] Martinez-Alier J, Munda G, O'Neill J. Weak comparability of values as a foundation for ecological economics. Ecological Economics. 1998;26(3):277-286.

[131] Flipo F, Schneider F, editors. Proceedings of the First International Conference on Economic DeGrowth for Ecological Sustainability and Social Equity. Paris, France. 18-19 April 2008. Availalbe from: http://events.it-sudparis.eu/degrowthcon ference/en/.

[132] Martinez-Alier J. Socially Sustainable Economic Degrowth. Forthcoming. In: Farley J, Malghan D, editors. Beyond Uneconomic Growth: Ecological Economics, and the Future of the Planet. London, UK; Edward Elgar: Forthcoming.

[133] Rijnhout L, Schauer T, editors. Socially Sustainable Economic Degrowth: Proceedings of a workshop in the European Parliament on 16 April 2009 upon invitation by Bart Staes MEP and The Greens / European Free Alliance. Available from: http://icta.uab.es/99_recursos/1253869447872.pdf

[134] Kallis G, Kerschner C, Martinez-Alier J. The economics of degrowth. Ecological Economics. 2012;84(0):172-180.

[135] Solow RM. Intergenerational Equity and Exhaustible Resources. The Review of Economic Studies. 1974;41(5):29-45.

[136] Smulders S. Endogenous Technological Change, Natural Resources, and Growth. In: Simpson RDP, Toman MAP, Ayres RUP, editors. Scarcity and Growth Revisited: Natural Resources and the Environment in the New Millenium. Washington, DC, USA: Resources for the Future; 2005.

[137] Ayres RU. Theories of Economic Growth. Fontainebleau, France: INSEAD; 1996.

[138] Barbier EB, Koch EW, Silliman BR, Hacker SD, 
Wolanski E, Primavera J, et al. Coastal EcosystemBased Management with Nonlinear Ecological Functions and Values. 2008;319(5861):321-323.

[139] Eisenack K, Scheffran J, Kropp JP. Viability analysis of management frameworks for fisheries. Environmental Modeling \& Assessment. 2006;11(1): 69-79.

[140] Bauer N, Baumstark L, Leimbach M. The REMIND-R model: The role of renewables in the low-carbon transformation-first-best vs. second-best worlds. Climatic Change. 2012;114(1):145-168.

[141] Stiglitz JE, Sen A, Fitoussi J-P, et al. Report by the Commission on the Measurement of Economic Performance and Social Progress. 2009.

[142] van den Bergh JCJM. The GDP paradox. Journal of Economic Psychology. 2009;30(2):117-135.

[143] Kubiszewski I, Farley J, Costanza R. The production and allocation of information as a good that is enhanced with increased use. Ecological Economics. 2010;69(6):1344-1354.

[144] Delong JB. Macroeconomics. Burr Ridge, IL, USA: McGraw-Hill Higher Education; 2002.

[145] Daly HE. Allocation, distribution, and scale: Towards an economics that is efficient, just, and sustainable. Ecological Economics. 1992;6(3):185193.

[146] Polimeni JM, Mayumi K, Giampietro M, Blake Alcott. The Jevons Paradox and the myth of resource efficiency improvements. Sterling, VA, USA: Earthscan; 2008.

[147] Farley J. The Role of Prices in Conserving Critical Natural Capital. Conservation Biology. 2008;22(6):1399-1408.
[148] Commoner B. The Closing Circle: Nature, Man, and Technology. New York, NY, USA: Knopf; 1971.

[149] Kuussaari M, Bommarco R, Heikkinen RK, Helm A, Krauss J, Lindborg R, et al. Extinction debt: A challenge for biodiversity conservation. Trends in Ecology \& Evolution. 2009;24(10):564-571.

[150] IPCC. Climate Change 2013. The Physical Science Basis Summary for Policymakers. Geneva, Switzerland: United Nations; 2013. Available from: http://www.ipcc.ch/.

[151] Anderson TL. Donning Coase-Coloured Glasses: A Property Rights View of Natural Resource Economics. Australian Journal of Agricultural and Resource Economics. 2004;48(3):445-462.

[152] Coase R. The Problem of Social Cost. Journal of Law and Economics. 1960;3(1):1-44.

[153] Benkler Y. Coase's Penguin, or, Linux and The Nature of the Firm. Yale Law Journal. 2002;4(3):369-446.

[154] Henry C, Stiglitz JE. Intellectual Property, Dissemination of Innovation and Sustainable Development. Global Policy. 2010;1(3):237-251.

[155] Dealbook. Speedy New Traders Make Waves Far From Wall Street. New York, NY, USA: New York Times; 17 May 2010.

[156] Hudson M. Higher Taxes on Top 1\% Equals Higher Productivity. The Real News Network; 2011. Available from: http://therealnews.com /t2/index.php?option=com_content\&task=view\& id=31\&Itemid=74\&jumival=6000:

[157] Bank for International Settlements. Triennial Central Bank Survey; Foreign exchange turnover in April 2013. Preliminary global results. Available from: http://www.bis.org. 